\title{
Selection for asexual reproduction in an Antarctic polychaete worm
}

\author{
John S. Oliver \\ Moss Landing Marine Laboratories, Moss Landing, California 95039, USA
}

\begin{abstract}
The Antarctic oweniid polychaete Myriochele cf. heeri frequently reproduced asexually by binary fission. The frequency of asexual reproduction was related to size-selective mortality and was highest (nearly $30 \%$ of the population) in a constant physical environment where the important potential selective forces are biological. Asexual individuals were abundant in a dense assemblage of Antarctic infauna. Individuals produced by fission had a size refuge from all important sources of mortality, especially crustacean predators that kill the larvae and juveniles of other soft-bodied infauna. Asexual reproduction was rare in Antarctic habitats where larval invasion was more likely and there was little refuge in size from various sources of adult mortality. No asexual reproduction was observed in an Alaskan species, $M$. oculata, living in habitats that were frequently disturbed by physical and biological processes.
\end{abstract}

\section{INTRODUCTION}

There has been considerable discussion of the advantages of sexual and asexual reproduction in the life history of a species (e.g. Williams, 1975; MaynardSmith, 1978). In general, sexual propagules are widely dispersed during periods of environmental change or uncertainty, while asexual reproduction occurs close to the parent during more benign periods (Williams, 1975). In addition, asexual reproduction often occurs in physically disturbed or isolated habitats where a single asexual individual can establish a new colony. These habitats also harbor relatively few competing, predatory or pathogenic species (Levins, 1975; Glesener and Tilman, 1978; Maynard-Smith, 1978). Sex and genetic recombination, in contrast, may be necessary adaptations of a species living in a biologically complex environment, where there is a continuous appearance of qualitatively new selective forces (Maynard-Smith, 1978). This biological complexity may be best developed in physically uniform environments (Sanders, 1968; Maynard-Smith, 1978). No single model accommodates these various correlations and ideas (Williams, 1975; Maynard-Smith, 1978).

The relation between asexual reproduction and the physical and biological environment is poorly understood in marine animals. There are few comparative studies of asexual populations within a single species or of asexual reproduction in closely-related species (e.g. Francis, 1979; Sebens, 1982). In particular, asexual budding, fission, and fragmentation among the large group of polychaete worms show little pattern of geographical occurrence (Schroeder and Hermans, 1975).

In this paper, I relate geographical variations in the frequency of asexual reproduction within an Antarctic polychaete species, and between closely-related Antarctic and Alaskan species to the physical and biological environment, especially to size-selective mortality. Contrary to some arguments (MaynardSmith, 1978), asexual reproduction in Myriochele is best developed in a constant physical environment where complex biological interactions provide the major potential selective forces. The geographical patterns, however, are consistent with Williams' strawberry-coral model (Williams, 1975).

\section{MATERIALS AND METHODS}

Antarctic bottom populations were sampled along the eastern shore of McMurdo Sound, at the jetty near McMurdo Station, and along the western shore at New Harbor and Marble Point (Fig. 1). The western areas were approximately $60 \mathrm{~km}$ from the eastern site. All study areas were in 20 to $40 \mathrm{~m}$ of water. Monthly 


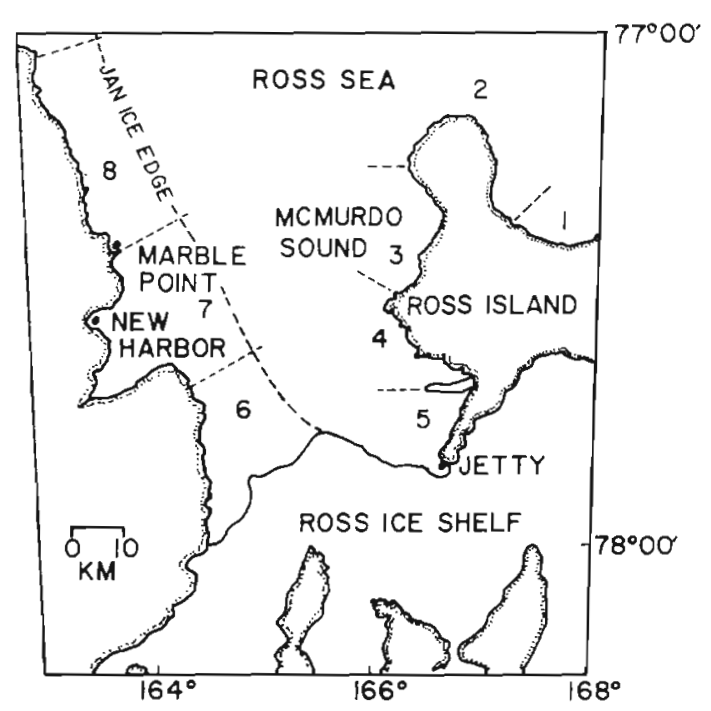

Fig. 1. McMurdo Sound, Antarctica showing the 8 geographical regions where icebergs were counted, and the major study areas on east (jetty area), and west shores (New Harbor, Marble Point)

samples were taken at the jetty area from Sep 1975 to Jan 1976, and from Feb to Aug 1977. The 2 western sites were sampled only during Nov and Dec 1976. Infaunal invertebrates were collected by hand-held diver corers (area $=0.018 \mathrm{~m}^{2}$; length $=15 \mathrm{~cm}$ ). Cores were washed over a $0.25 \mathrm{~mm}$ screen, and residues preserved in a solution of $4 \%$ formaldehyde. All the macrofaunal invertebrates were identified and counted.

Length and width (first setiger) of the oweniid polychaete Myriochele cf. heeri Malmgren 1867 were measured, and the state of asexual reproduction recorded: no fission, early fission (no head or tail regeneration), late fission (head and tail regeneration), and final stage (2 well-developed individuals in 1 tube).

Asexual reproduction was easily distinguished from breakage during sample procurement and processing, and was always indicated by 2 fission parts in the same tube. Transverse, binary fission occurred in the upper third of the body, generally at setigers 6 to 8 . Body cavity and tube were carefully examined for eggs in all specimens. Eggs were conspicuous under a dissecting microscope. No brooding was observed in the tube. Individuals were designated ovigerous if eggs were located in the body.

Alaskan bottom communities containing dense populations of Myriochele oculata (Zachs, 1923) were sampled near Nome, Alaska in Jun 1981. Sample procurement and processing were the same as in the Antarctic. Further descriptions of the Alaskan site and methods are presented in Oliver et al. (1983). $M$. oculata were examined for eggs and signs of asexual reproduction. In addition to measurements of body length, individuals $<5 \mathrm{~mm}$ in length were counted separately as juveniles.

Larger, epifaunal invertebrates in the Antarctic areas were counted from $1 \mathrm{~m}^{2}$ photographic quadrants along permanent and random transects made during the austral summer of 1976 . Only the motile epifauna that disturb surface sediments were counted, including the ophiuroid Ophionotus victoriae Bell 1902, the echinoid Brisaster sp., and the pecten Adamussium colbecki Smith 1902. In Alaska, the only large, motile epifaunal invertebrate was the sea star Asterias amurensis Ives 1891 , which was counted along $100 \mathrm{~m}^{2}$ transects by SCUBA divers using underwater tape recorders.

Finally, the grounding of icebergs in different shore regions of McMurdo Sound was determined from photographs taken by US Tricamera Aerial Surveys (1956-70), and from personal observations during 1974-77 (Oliver, 1980). Geographical areas were approximately the same size but were selected primarily because of known differences in habitats and benthic communities. The same number of photographs were examined for each area during months of sea ice cover. The range in iceberg number observed in photographs or surveys is reported.

\section{RESULTS}

\section{Eastern McMurdo Sound}

A large number of Myriochele cf. heeri reproduced asexually by binary fission along eastern McMurdo Sound (jetty area). During Nov and Dec, when comparative samples were available from other parts of the sound, $23 \%$ of the jetty population was involved in asexual fission (Table 1). During the 10 mo of the year when fission was observed (Fig. 2), $12 \%$ of the jetty population was reproducing asexually (Table 2).

There was a distinct seasonal pattern in asexual fission of Myriochele cf. heeri (Fig. 2). Asexually reproducing forms were absent in Feb and Mar. Early fission products first occurred in Apr and predominated until Jun. Late fission was common until Nov and Dec. Finally, 2 well-developed individuals were usually present in single tubes in Dec and Jan. At the earliest stages of fission, the 2 fission products were relatively large, and were retained in a tough, well-developed tube. It was unclear how these 2 individuals separated into 2 distinct tubes. Individuals produced asexually were much larger than the juveniles of species with pelagic or demersal larvae ( 6 to 11 compared to 0.5 to $2 \mathrm{~mm})$.

The number of worms with empty guts showed a 
the year of sampling. Together, they formed a very dense infaunal assemblage (Dayton and Oliver, 1977). The soft-bodied infauna were all polychaetes, with the exception of 1 species of burrowing anemone. Small species and small individuals of soft-bodied infauna were extremely rare in this dense assemblage (Oliver, 1980; Oliver et al., 1982). I found no small individuals or juveniles of $M$. cf. heeri (<5 mm in length) as single occupants of tubes during more than 1 yr of sampling at the jetty area (Table 2). The few small individuals observed were always part of a fission pair in the same tube. Over $99 \%$ of the fission products and whole individuals of $M$. cf. heeri were $>5 \mathrm{~mm}$ in length ( $\mathrm{n}=2323$ ).

There were over $87500 \mathrm{~m}^{-2}$ peracarid crustaceans in the dense assemblage at the jetty, and $36 \%$ of these were infaunal amphipods and tanaids (Table 1) that were known to kill small, soft-bodied forms, either by direct consumption or by trampling or other disturbance (Oliver, 1980; Oliver et al., 1982). Phoxocephalid amphipods eat small polychaetes, nematodes, and some crustaceans (Oliver et al., 1982). Heterophoxus videns Barnard 1930 and Nototanais dimorphus Beddard $\mathbf{1 8 8 6}$ are the most important source of mortality to small, soft-bodied forms, and undoubtedly accounted for the absence of these forms in the dense assemblage (Oliver, 1980; Oliver et al., 1982).

There were no epifaunal invertebrates or fishes that dug into surface sediments and disrupted the infauna at the jetty area (Table 1). Only the sea star Odontaster validus Koehler 1906 was present (much less than $1 \mathrm{~m}^{-2}$ ). This species did not dig into sediment (own obs.), and everted the stomach over carrion and prey such as other asteroids, hydroids, and sponges (Dayton et al., 1974). The nototheneid fishes fed on invertebrates at the sediment surface and did not dig into the sediment for food (Oliver, 1980).

\section{Western McMurdo Sound}

Unlike the eastern sound, asexual reproduction was rare along western McMurdo Sound (Table 1). Only 1 individual was found in a late stage of binary fission at New Harbor, and no asexual worms were found at Marble Point. During the same months at the jetty area, Nov and Dec, $23 \%$ of the Myriochele cf. heeri were reproducing asexually (Table 1; Fig. 2). The low frequency of occurrence of asexual forms along the west sound was not related to a small sample size ( $\mathrm{n}=$ 300 individuals). No asexual forms were observed in several hundred additional individuals examined qualitatively from Marble Point samples. Unfortunately, these samples were lost in a fire at Scripps Institution of Oceanography before additional quan- titative measurements were made. Only 1 ovigerous female was observed in samples from western McMurdo Sound.

Individuals from the New Harbor population were significantly larger (Kolmogrov-Sminov test, $\mathrm{p}<$.05) than those at the jetty site. The size differences between individuals at Marble Point and at the jetty area followed the same trend, but were non-significant $(p>.05)$. The larger size at the westem sites, New Harbor and Marble Point, may be related to less frequent binary fission $(0$ to $1 \%$ compared to $23 \%$; Table 1).

The infaunal populations along western McMurdo Sound were much less abundant than those at the jetty area along the east shore (Dayton and Oliver, 1977). In particular, the numbers of amphipod and tanaid crustaceans that kill small, soft-bodied forms such as juvenile Myriochele were at least an order of magnitude less abundant along the west shore (Table 1). Although the infaunal communities were considerably less dense, the number of large epifaunal invertebrates that disturbed surface sediments was much higher on the west shore (Table 1). These epifauna included Ophionotus victoriae, Brisaster sp., and Adamussium colbecki, all of which plowed and dug into the top 1 to $5 \mathrm{~cm}$ of the sediment during feeding and burrowing. They reworked the sea floor, producing extensive, small-scale topographic relief (Dayton and Oliver, 1977).

Table 3. Number of icebergs grounded nearshore $(<50 \mathrm{~m}$ depth) in 8 geographical regions in McMurdo Sound (Fig. 1). Ranges in number of bergs from aerial photographs and aerial surveys

\begin{tabular}{|cc|}
\hline Region & Number of icebergs \\
\hline 1 & $10-20$ \\
2 & $10-15$ \\
3 & $4-8$ \\
4 & $4-8$ \\
5 & $1-2$ \\
6 & 0 \\
7 & 0 \\
8 & $10-15$ \\
\hline
\end{tabular}

Finally, icebergs commonly grounded in the Marble Point area (Table 3 ). Grounded bergs produced wide (10 to $100 \mathrm{~m}$ ) paths where the sediment and fauna were highly disrupted. In some regions, the general topography of large areas was modified by iceberg gouging. At Marble Point, grounded bergs plowed paths 20 to $50 \mathrm{~cm}$ below the undisturbed level bottom (own obs.). No grounded icebergs were observed in shallow water $(<50 \mathrm{~m})$ in New Harbor, or south of Hut Point where the jetty area is located (Table 3 ). 


\section{Alaskan species}

Myriochele oculata is morphologically similar to $M$ cf. heeri, differing primarily in maximum size, and in the presence of distinct eye spots. Unlike the Antarctic species, ovigerous females and juveniles were frequently encountered (Table 2 ). No asexual reproduction was discovered in this species. In addition to the data presented in Table 2 , no asexual reproduction was encountered in examining several thousand individuals from other core samples taken near Nome, Alaska (Oliver et al., 1983).

Myriochele oculata did not co-occur with a crustacean fauna that kills small, soft-bodied infauna; however, one large epifaunal animal was abundant, and frequently dug into surface sediments to extract prey (Oliver et al., 1983). This was the sea star Asterias amurensis. At the Cape Nome area, there were $37 \pm 17$ per $100 \mathrm{~m}^{2}(\overline{\mathrm{X}}=$ S.D.; $\mathbf{n}=43)$

\section{DISCUSSION}

This is the first report of asexual reproduction in an oweniid polychaete worm. Asexual reproduction was recently reported in an Arctic maldanid polychaete (Curtis, 1977), which is morphologically similar to Myriochele. I also found asexual reproduction by binary fission in 2 species of maldanid polychaetes living in McMurdo Sound (Oliver, 1980). In general, however, asexual reproduction has been overlooked in both the oweniid and maldanid polychaetes (e.g. Schroeder and Hermans, 1975).

There was a distinct seasonal pattem in asexual reproduction. The number of fission products was greatest along the east shore of McMurdo Sound during the spring and early summer (over $20 \%$ of the population). No fission products were recognized in late summer when food was abundant and empty guts were rare. More empty guts were present during peak periods of fission. Although asexual division is inhibited by continuous feeding in some species (Sebens, 1980), there is little evidence for a causal relation between fission and food in Myriochele. However, the timing of fission produces regenerated individuals during the period of high planktonic and benthic productivity in McMurdo Sound (Dayton and Oliver, 1977 ; see Sebens, 1982 for other seasonal patterns of fission).

The high incidence of asexual reproduction in the dense assemblage may result from a special set of selective forces involving biological interactions among the small infauna. My hypothesis is that asexual forms enjoy a size refuge from the crustacean predators, and thus accumulate in the dense assemblage. Sources of mortality were inferred from the abundances and diets of predators and from feeding experiments. Small species and small individuals of soft-bodied infauna (mostly polychaete worms) were extremely rare in the dense assemblage (Oliver et al., 1982). Laboratory and field feeding experiments showed that the crustaceans, particularly Heterophoxus videns and Nototanais dimorphus, were the major source of mortality to larvae and juveniles recruiting into the dense assemblage (Oliver, 1980; Oliver et al., 1982). In contrast, adults were not consumed or otherwise killed by the crustaceans. They had a refuge in size (Oliver, 1980). No other important source of mortality to large, soft-bodied individuals was observed in the dense assemblage. Nototheneid fishes, epifaunal invertebrates, and other infaunal predators rarely killed larger individuals (Oliver, 1980). In addition, the physical environment was highly constant, and not disruptive (Dayton et al., 1974). The 2 physical processes that do disrupt large areas of the sea floor, anchor ice formation and iceberg scour, did not disturb the dense jetty assemblage (Oliver, 1980; Table 3).

Asexual reproduction was less frequent where larval invasion was more likely, and where larger individuals did not have a refuge in size. Along the west shore of McMurdo Sound, at New Harbor and Marble Point, there was no dense crustacean fauna capable of causing high mortality to settling larvae and juveniles. There were, however, many large epifaunal invertebrates that frequently disrupted the sediment and infauna during feeding and burrowing (Table 1; Dayton and Oliver, 1977). Although this disturbance undoubtedly affected small individuals, large individuals of the soft-bodied infauna did not have a refuge from epifaunal disturbance. Furthermore, iceberg grounding was common at Marble Point (Table 3), scouring large areas of the sea floor and disrupting all size classes of the infauna. As predicted. asexual reproduction was relatively rare along western McMurdo Sound.

Asexual reproduction has not been observed in other species of Myriochele. I have examined $M$. oculata from Alaska and $M$. heeri from the California coast. Both species live in much more variable and disruptive physical environments than $M$. cf. heeri in McMurdo Sound. In Alaska, populations of $M$. oculata contain many small juveniles ( 1 tube $\left.^{-1}\right)$, and ovigerous females, but show no signs of asexual reproduction (Table 2). The Alaskan bottoms were scoured by strong water currents, large wave swell, and grounded ice. Fresh water and heavy particulate input were extensive. The bottom was intensively reworked by epifaunal invertebrates, walruses, and gray whales (Oliver et al., 1983).

Along the California coast, populations of $\mathrm{MY}$ - 
riochele heeri also contained many juvenile sizes and ovigerous individuals and showed no asexual reproduction (own obs.; S. Hamilton, pers. comm.). These nearshore shelf communities were also exposed to extensive physical disturbances, especially wave action (Oliver et al., 1980).

The Alaska and California areas are not environments where asexual reproduction would be predicted. There is no dense crustacean or similar fauna that provides a strong block to larval recruitment, and there is no evidence of a refuge in size from predators and other biological and physical sources of mortality (Oliver et al., 1980, 1983). Larvae can penetrate the bottorn communities, and asexual forms, if produced, would have little refuge allowing their accumulation.

Unfortunately, it was impossible to explore the potential trade-offs between sexual and asexual reproduction in Myriochele cf. heeri. Sexual reproduction, as indicated by numbers of ovigerous females, was rare. I found only 2 ovigerous females along the east shore, and only 1 ovigerous female along the west shore of McMurdo Sound. Intraspecific comparisons could not be made. However, sexual reproduction was frequent in the Alaskan species $M$. oculata (Table 2).

Although asexual reproduction is generally related to colonization of disturbed or isolated habitats (Maynard-Smith, 1978), the Antarctic physical environment on the east shore of McMurdo Sound was constant and not disruptive. Biological interactions appeared to be the major selective forces accounting for the accumulation of asexual individuals in the dense assemblage.

As predicted by Williams' strawberry-coral model (Williams, 1975), asexual reproduction in Myriochele was frequent in habitats where parents are successful, and sexual reproduction established populations in new and less predictable habitats. Williams (1975) was primarily interested in why sex is adaptive. I am primarily interested in why asexual reproduction is only frequent in a Myriochele population along the east shore of McMurdo Sound. Asexual reproduction is extremely rare in oweniid polychaetes, including other populations of Myriochele, and in the morphologically similar maldanids. It is unreported for either family in the most extensive and recent review of polychaete reproduction (Schroeder and Hermans, 1975). Few, if any, infaunal communities have the extremely high levels of juvenile mortality and very low levels of adult mortality that characterize the dense assemblage of the east sound. This unique environment apparently selected for asexual reproduction in Myriochele.

Acknowledgements. I thank P. Dayton for his helpful criticisms and good humor. P. Dayton, K. Fauchald, P. Frank, G. Gillingham, C. Hannan, C. Jong, J. Pearse, K. Sebens, and M.
Silberstein improved an earlier manuscript. S. Hamilton compiled much of the polychaete data; P. Slattery helped with all aspects of the study, and $\mathrm{R}$. Stelow typed the manuscript. The work was supported by a National Science Foundation, Division of Polar Programs grant to P. Dayton and Scripps Institution of Oceanography (DPP-75-08074).

\section{LITERATURE CITED}

Curtis, M. A. (1977). Life cycles and population dynamics of marine benthic polychaetes from the Disko Bay area of west Greenland. Ophelia 16: 9-58

Dayton, P. K., Robilliard, G. A., Dayton, L. B., Paine, P. T. (1974). Biological accommodation in the benthic community at McMurdo Sound, Antarctica. Ecol. Monogr. 44: 105-126

Dayton, P. K., Oliver, J. S. (1977). Antarctic soft-bottom benthos in oligotrophic and eutrophic environments. Science, N.Y. 197: 55-58

Fager, E. W. (1964). Marine sediments: effects of a tubebuilding polychaete. Science, N.Y. 143: 356-359

Francis, L. (1979). Contrast between solitary and colonial lifestyles in the sea anemone Anthopleura elegantissima. Am. Zool. 19: 669-681

Glesener, R. R., Tilman, D. (1978). Sexuality and the components of environmental uncertainty: clues from geographic parthenogenesis in terrestrial animals. Am. Nat. 112: $659-673$

Levins, D. A. (1975). Pest pressure and recombination systems in plants. Am. Nat. 109: 437-451

Maynard-Smith, J. (1978). The evolution of sex. Cambridge University Press, London

Oliver, J. S. (1980). Processes affecting the organization of marine soft-bottom communities in Monterey Bay, California and McMurdo Sound, Antarctica. Ph. D. thesis, University of California, San Diego

Oliver, J. S., Slattery, P. N., Hulberg, L. W., Nybakken, J. W. (1980). Relationships between wave disturbance and zonation of benthic invertebrate communities along a subtidal high-energy beach in Monterey Bay, California. Fish. Bull. U.S. 78: 437-454

Oliver, J. S., Oakden, J. M., Slattery, P. N. (1982). Phoxocephalid amphipod crustaceans as predators of larvae and juveniles in marine soft-bottom communities. Mar. Ecol. Prog. Ser. 7: 179-184

Oliver, J. S., Slattery, P. N., O'Connor, E. F., Lowry, L. F. (1983). Walrus feeding in the Bering Sea: a benthic perspective. Fish. Bull. U.S. 81: 501-512

Sanders, H. L. (1968). Marine benthic diversity: a comparative study. Am. Nat. 102: 243-282

Schroeder, P. C., Hermans, C. O. (1975). Annelida: Polychaeta. In: Geise, A. C., Pearse, J. S. (ed.) Reproduction of marine invertebrates, Vol. III. Academic Press, New York, p. $1-213$

Sebens, K. P. (1980). The regulation of asexual reproduction and indeterminate body size in the sea anemone Anthopleura elegantissima (Brandt). Biol. Bull. mar. biol. Lab., Woods Hole 158: 370-382

Sebens, K. P. (1982). Asexual reproduction in Anthopleura elegantissima (Anthozoa: Actiniaria): seasonality and spatial extent of clones. Ecology 63: 434-444

Williams, G. C. (1975). Sex and evolution. Princeton University Press, Princeton, New Jersey, USA 